\title{
TEKNIK RELAKSASI DENGAN ALAT MUSIK TRADISIONAL MANDAR MENURUNKAN SKALA NYERI PADA IBU BERSALIN KALA I FASE AKTIF
}

\author{
Satriani G ${ }^{\bowtie}$, Abbas Mahmud \\ Jurusan Kebidanan Poltekkes Kemenkes Mamuju
}

\section{ARTICLE INFO \\ Article history}

Submitted : 2020-01-26

Revised : 2020-01-29

Accepted : 2020-08-20

\section{Keywords:}

Labor Pain

Relaxation Techniques

Mandar Music

\section{Kata Kunci:}

Nyeri Persalinan

Teknik Relaksasi

Musik Mandar

$\overline{\triangle \text { Corresponding Author: }}$

\begin{abstract}
The direct causes of maternal mortality rate are bleeding, eclampsia, abortion, infection, and prolonged labor. Maternal mortality rate can be minimized by safe, clean help, and prevent complications. Labor is a process that begins with uterine contractions causing progressive dilation of the cervix, birth of a baby, and labor of placenta and it is a natural process. This study aims to see the effectiveness of instrumental music relaxation techniques using traditional musical instruments on the labor process of inpartu mothers when phase I was active at Community Health Center in Tampa Padang, Mamuju. This study is an experimental study with a pre-experimental conception and use one group pretest-posttest conception with the population of maternal mothers at Tampa Padang Community Health Centre. The samples are pregnant women who entered the delivery room with inpartu diagnosis of the first stage/phase is active or the opening stage. The sampling technique was consecutive sampling which could be done by 31 people. The data then being analyzed with univariable analysis and bivariable analysis using the Wilcoxon Test with a significance level of 0.05 to see the interface relationship with the decrease in pain scale. The results showed a relationship in reducing pain scale of mothers who were given musical intervention with Mandar traditional musical instruments where $p=0.000$. The conclusion of this study shows that by applying instrumental music relaxation techniques with traditional Mandar musical instruments, mothers can adjust to pain during labor so that it can reduce the pain scale in mothers in labor when phase 1 is active.
\end{abstract}

Penyebab langsung dari AKI yaitu perdarahan, eklampsia, abortus, infeksi, dan partus lama. Angka kematian ibu bersalin dapat diminimalkan dengan pertolongan yang aman, bersih dan mencegah terjadinya komplikasi. Persalinan adalah suatu proses yang dimulai dengan adanya kontraksi uterus yang menyebabkan terjadinya dilatasi progresif dari serviks, kelahiran bayi, dan kelahiran plasenta, dan proses tersebut merupakan proses alamiah. Penelitian ini bertujuan untuk mengetahui efektifitas teknik relaksasi musik instrumental dengan menggunakan alat musik tradisional mandar terhadap proses persalinan ibu Inpartu kala I fase aktif di Puskesmas Tampa Padang Kabupaten Mamuju. Penelitian ini merupakan penelitian eksperimen dengan rancangan pra eksperimen dan menggunakan design one group pretest - posttest dengan populasi ibu bersalin yang ada di Puskesmas Tampa Padang. Sampel adalah ibu hamil yang masuk kamar bersalin dengan diagnose inpartu kala I fase aktif atau kala pembukaan dengan teknik pengambilan sampel adalah consecutive sampling berjumlah 31 orang. Data dianalisa dengan analisis univariabel dan analisis bivariabel dengan menggunakan Uji Wilcoxon dengan derajat kemaknaan 0,05 untuk mengetahui hubungan interfensi dengan penurunan skala nyeri. Hasil penelitian menunjukkan adanya hubungan bermakna dalam penurunan skala nyeri pada ibu yang diberikan intervensi relaksasi musik dengan alat musik tradisional mandar dimanan $\mathrm{p}=0,000$. Kesimpulan penelitian ini menunjukkan bahwa dengan menerapkan teknik relaksasi musik instrumental dengan alat musik tradisional Mandar ibu dapat beradaptasi dengan nyeri dalam persalinannya sehingga dapat menurunkan skala nyeri pada ibu bersalin kala I fase aktif.

Satriani G

Jurusan Kebidanan Poltekkes Kemenkes Mamuju

Telp. 085255522992

Email: cantika100@gmail.com 


\section{PENDAHULUAN}

Angka Kematian Ibu (AKI) merupakan cerminan dari tingkat kesehatan masyarakat. Pelayanan kesehatan maternal dan neonatal merupakan suatu unsur kesehatan dimana AKI merupakan barometer kemajuan pelayanan kesehatan. Mortalitas dan morbiditas pada wanita hamil dan bersalin adalah masalah besar di negara berkembang. Kematian saat melahirkan biasanya menjadi faktor utama mortalitas wanita usia muda pada masa puncak produktivitasnya.

Penyebab langsung dari AKI yaitu perdarahan, eklampsia, abortus, infeksi, dan partus lama. Angka kematian ibu bersalin dapat diminimalkan dengan pertolongan yang aman, bersih dan mencegah terjadinya komplikasi. Persalinan adalah suatu proses yang dimulai dengan adanya kontraksi uterus yang menyebabkan terjadinya dilatasi progresif dari serviks, kelahiran bayi, dan kelahiran plasenta, dan proses tersebut merupakan proses alamiah. (Rohani, 2011).

Keberhasilan proses persalinan dipengaruhi oleh beberapa faktor yaitu power, passanger, passageway, psikologis pasien dan penolong persalinan. Faktor power adalah his atau kontaksi uterus dan tenaga ibu mengedan, faktor power ini juga dipengaruhi oleh psikologi ibu melahirkan dan peran penolong persalinan serta dukungan keluarga. Setiap ibu yang akan memasuki masa persalinan maka akan muncul perasaan takut, khawatir, ataupun cemas terutama pada ibu primipara. Perasaan takut dapat meningkatkan nyeri, otot-otot menjadi tegang dan ibu menjadi cepat lelah yang pada akhirnya akan menghambat proses persalinan (Yeyeh R.A, 2012).

Nyeri persalinan dapat menimbulkan stres yang menyebabkan pelepasan hormon stres yang berlebihan seperti katekolamin dan steroid. Hormon ini dapat menyebabkan ketegangan otot polos dan vasokontriksi pembuluh darah sehingga terjadi penurunan kontraksi uterus, penurunan sirkulasi uteroplasenta, pengurangan aliran darah dan oksigen ke uterus yang membuat impuls nyeri bertambah banyak dan juga memperlambat proses kemajuan persalinan. Kemajuan proses persalinan yang terhambat dapat menjadikan persalinan fisiologis menjadi patologis (Mander, Rosemary, 2003).

Musik memiliki manfaat untuk ibu dapat melewati proses persalinan kala I fase aktif yaitu fase dimana pembukaan serviks $4 \mathrm{~cm}$ sampai $10 \mathrm{~cm}$ atau pembukaan lengkap. Fase aktif berlangsung lebih cepat dan ibu semakin merasakan nyeri. Musik dapat memberikan energy dan perintah melalui irama sehingga dapat membantu ibu dalam mengurangi rasa nyeri selama proses persalinan.

\section{METODE PENELITIAN Jenis Penelitian}

Jenis penelitian yang digunakan adalah Eksperimen dengan rancangan pra eksperimen dan menggunakan design one group pretestposttest.

\section{Lokasi dan Waktu Penelitian}

Lokasi penelitian di Puskesmas Tampa Padang Kabupaten Mamuju Propinsi Sulawesi Barat. Waktu penelitian dilaksanakan pada Bulan April - September Tahun 2018.

\section{Populasi dan Sampel}

Populasi dalam penelitian ini adalah ibu bersalin yang ada di wilayah kerja Puskesmas Tampa Padang Kabupaten Mamuju Propinsi Sulawesi Barat. Sampel dalam penelitian ini adalah semua ibu bersalin yang masuk dengan kala I atau kala pembukaan yang ada di Puskesmas Tampa Padang Kabupaten Mamuju Propinsi Sulawesi Barat. Dalam pengambilan sampel tehnik yang digunakan adalah consecutive sampling dimana semua subjek yang datang dan memenuhi kriteria pemilihan dimasukkan dalam penelitian sampai besar sampel yang diperlukan terpenuhi. Besar sampel adalah 31 responden $(n=31)$.

Kriteria inklusi dalam pengambilan sampel adalah ibu inpartu dengan usia kehamilan aterm, menandatangani inform consent, persalinan kala I fase aktif, janin tunggal hidup, presentasi belakang kepala, rencana melahirkan normal, tidak dilakukan induksi persalinan, tidak ada riwayat komplikasi selama masa prenatal maupun penyakit penyerta kehamilan, tidak diberi obatobatan pengurang nyeri, persalinan didampingi suami atau keluarga terdekat, dapat berkomunikasi dengan baik, ditolong oleh bidan dan bersedia menjadi sampel dalam penelitian ini. Kriteria eksklusi adalah ibu bersalin yang tidak kooperatif, denyut jantung janin tidak normal dan ketuban negatif. 


\section{Pengumpulan Data}

Pengumpulan data dilakukan dengan menggunakan alat pengumpulan data berupa lembar observasi berisi checklist skala nyeri dengan menggunakan skala nyeri sederhana dimana ibu dapat menentukan sendiri skala nyeri yang dirasakan saat his.

Skala nyeri terdiri dari 5 kategori yaitu skala tidak nyeri kategori skala 0 , skala nyeri ringan kategori skala $1-3$, skala nyeri sedang kategori skala $4-6$, skala nyeri berat terkontrol kategori skala $8-9$, skala nyeri berat tidak terkontrol kategoti skala 10.

\section{Pengolahan dan Analisis Data}

Pengolahan data dilakukan dengan program SPSS yang terlebih dahulu melalui tahap editing dimana data yang ada dalam formulir pengumpulan data diperiksa kelengkapan, keterbacaan, kesesuaian jawaban. Selanjutnya tahap entry data dimana data diinput ke dalam lembar kerja program SPSS. Terakhir tahap cleaning data dilakukan pada semua lembar kerja untuk membersihkan kesalahan yang mungkin terjadi selama proses input data.

\section{HASIL PENELITIAN}

Penelitian efektifitas relaksasi musik instrumental tradisional Mandar terhadap nyeri persalinan kala I fase aktif yang dilaksanakan di Puskesmas Tampa Padang kabupaten Mamuju Propinsi Sulawesi Barat, berlangsung kurang lebih 5 bulan yang terhitung dari bulan April hingga Agustus tahun 2018.

Setelah dilakukan pengolahan dan analisis data yang disesuaikan dengan tujuan penelitian maka hasil penelitian disajikan dalam bentuk tabel dengan analisis univariabel dan bivariabel. Analisis univariabel digunakan untuk memperoleh gambaran umum karakteristik responden dari variable yang diteliti yang dipaparkan dalam bentuk distribusi frekuensi. Sedangkan analisis bivariabel menggunakan uji yang disebut Uji Wilcoxon derajat kemaknaan 0,05. Apabila nilai $\mathrm{p}<0,05$, menunjukkan bahwa ada hubungan antara variabel bebas dengan variabel terikat. Apabila nilai $\mathrm{p}>0,05$, menunjukkan bahwa tidak ada hubungan antara variabel bebas dengan variabel terikat. Maka hasil penelitian dapat disajikan sebagai berikut:

Tabel 1. Distribusi Responden berdasarkan Umur Ibu, Pendidikan, Jumlah Persalinan

\begin{tabular}{lcc}
\hline \multicolumn{1}{c}{ Karakteristik Responden } & Frekuensi (n) & Persen (\%) \\
\hline Umur (Tahun) & 3 & \\
$\leq 21$ & 24 & 10 \\
$21-35$ & 4 & 77 \\
$>35$ & & 13 \\
\hline Pendidikan & 14 & \\
Sekolah Dasar & 9 & 45 \\
Sekolah Menengah Pertama & 6 & 29 \\
Sekolah Menengah Atas & 2 & 19 \\
Diploma/Sarjana & & 7 \\
\hline Jumlah Persalinan & 10 & \\
1 & 7 & 32 \\
2 & 7 & 23 \\
3 & 4 & 23 \\
4 & 1 & 13 \\
5 & 1 & 3 \\
7 & 1 & 3 \\
8 & 1 & 3 \\
\hline
\end{tabular}

Berdasarkan Tabel 1. menunjukkan dari 31 responden yang masuk kamar bersalin dan mengalami his atau kontraksi uterus yang disertai rasa nyeri di Puskesmas Tampa Padang didominasi oleh tingkat pendidikan SD
$(45,1 \%)$, dan yang terendah adalah persentase tingkat pendidikan Diploma/Sarjana adalah $6,5 \%$ atau sebanyak 2 orang. Untuk tingkat pendidikan SMP 9 orang (29.0\%) dan tingkat pendidikan SMA 6 orang (19.4\%). 
Dari 31 responden yang masuk kamar bersalinan dan mengalami his atau kontraksi uterus yang disertai rasa nyeri di Puskesmas Tampa Padang untuk karakteristik usia ibu didominasi oleh usia antara 21 - 35 tahun $(77,4 \%)$ yang merupakan kelompok usia produktif secara reproduksi. Usia kurang dari 20 tahun sebanyak 3 orang $(9.7 \%)$ dan usia lebih dari 35 tahun sebanyak 4 orang (12.9\%) dimana usia ini merupakan kelompok usia yang rentan terhadap resiko dalam persalinan.
Dari 31 responden yang masuk kamar bersalinan dan mengalami his atau kontraksi uterus yang disertai rasa nyeri di Puskesmas Tampa Padang dengan jumlah persalinan pertama sebesar $32,3 \%$ merupakan persentase persalinan yang paling tinggi dan persalinan yang paling kecil adalah persalinan ke-5,7 dan 8 sebesar $3.2 \%$.

Tabel 2. Distribusi Skala Nyeri sebelum dan setelah Intervensi $(n=31)$

\begin{tabular}{lcccc}
\hline \multirow{2}{*}{ Skala Nyeri } & \multicolumn{2}{c}{ Sebelum Intervensi } & \multicolumn{2}{c}{ Setelah Intervensi } \\
\cline { 2 - 5 } & $\mathbf{n}$ & $\mathbf{\%}$ & $\mathbf{n}$ & $\mathbf{\%}$ \\
\hline Tidak Nyeri & 0 & 0 & 1 & 3 \\
Nyeri Ringan & 0 & 0 & 8 & 27 \\
Nyeri Sedang & 5 & 16 & 14 & 47 \\
Nyeri Berat Terkontrol & 13 & 42 & 7 & 23 \\
Nyeri Berat Tidak terkontrol & 13 & 42 & 0 & 0 \\
\hline
\end{tabular}

Berdasarkan Tabel 2. memperlihatkan bahwa nyeri berat terkontrol dan nyeri berat tidak terkontrol sebelum dilakukan intervensi adalah sebesar 42\%. Setelah dilakukan intervensi dengan memperdengarkan musik instrumental dengan alat musik tradisional Mandar Calong, skala nyeri berat terkontrol yang sebelumnya $42 \%$ turun menjadi $23 \%$ sedangkan skala nyeri berat tidak terkontrol yang tadinya $42 \%$ menjadi $0 \%$ dan ibu inpartu kala I fase aktif yang sebelumnya tidak ada dengan kategori skala tidak nyeri menjadi terdapat $1 \mathrm{ibu}$ yang masuk dalam kategori skala tidak nyeri setelah dapat beradaptasi dengan nyeri yang dirasa dan rilek mendengarkan musik persalinan instrumental dengan alat musik tradisional Mandar. Dalam proses pemberian intervensi terdapat 1 orang ibu yang tidak bersedia menentukan skala nyeri yang dirasakan sehingga terdapat 1 sampel yang dalam status drop out.

\section{Tabel 3. Hasil Uji Test Statistik Wilcoxon Signed}

\begin{tabular}{cc}
\hline & $\begin{array}{c}\text { Skala Nyeri Setelah Intervensi - } \\
\text { Skala Nyeri Sebelum Intervensi }\end{array}$ \\
\hline $\mathrm{Z}$ & -4.818 \\
Asymp. Sig. (2-tailed) & .000 \\
\hline
\end{tabular}

Berdasarkan tabel 3. menunjukkan bahwa hasil uji statistik menggunakan Wilcoxon Sign Rank Test diatas didapatkan hasil yaitu dengan nilai P (0.000). Maka Ha diterima, yang berarti ada pengaruh yang signifikan dari pemberian teknik relaksasi dengan musik instrumental yang menggunakan alat musik tradisional Mandar yaitu calong terhadap penurunan skala nyeri pada ibu bersalin kala I fase aktif di Puskesmas Tampa Padang Mamuju. Musik instrumental dengan alat musik tadisional Mandar yaitu calong efektif menurunkan skala nyeri ibu bersalin kala I fase aktif dimana ibu dapat beradaptasi terhadap nyeri dan dapat merasa lebih rileks dalam menjalani proses persalinan.

\section{PEMBAHASAN}

Penelitian ini menggunakan tehnik relaksasi dengan memperdengarkan musik instrumental Mandar yang menggunakan alat musik tradisional Mandar yaitu Calong dan dibuat khusus dengan tujuan agar ibu dapat beradaptasi dengan nyeri serta dapat rileks 
dalam menghadapi persalinan. Dari penelitian yang telah dilakukan terjadi perubahan nyeri yang di rasakan ibu dalam kala I fase aktif persalinan. Dimana sebelum dilakukan intervensi, terdapat ibu dengan tingkat nyeri berat terkontrol dan kemudian setelah dilakukan intervensi yaitu dengan memperdengarkan musik instrumental Mandar maka tingkat nyeri berat terkontrol tidak lagi ada responden yang merasakan.

Hasil penelitian ini menunjukkan adanya hubungan antara pemberian tehnik relaksasi musik dengan penurunan skala nyeri. Berdasarkan hasil uji statistik menggunakan Wilcoxon Sign Rank Test didapatkan hasil nilai $\mathrm{P}$ (0.000). Maka Ha diterima, artinya ada pengaruh yang signifikan pemberian teknik relaksasi musik instrumental Mandar menggunakan alat musik tradisional Mandar terhadap penurunan skala nyeri pada ibu bersalin kala I fase aktif.

Berdasarkan hasil penelitian lain, didapatkan rata-rata intensitas nyeri yang diberikan terapi musik instrumental adalah pada skala 6,00 dan rata-rata intensitas nyeri yang tidak diberikan terapi musik instrumental adalah pada skala 7,92 . Ada pengaruh terapi musik instrumental terhadap penurunan intensitas nyeri persalinan kala 1 fase aktif pada ibu primigravida (Husna,Ulya, 2010).

Sejalan dengan penelitian yang dilakukan NK Soyomani dkk, dengan menggunakan musik Mozart dan Musik tradisional Bali menyimpulkan bahwa ada perbedaan nyeri persalinan setelah mendengarkan musik klasik Mozart dan musik tradisional Bali dibandingkan kelompok kontrol (yang tidak mendengarkan musik).

\section{KESIMPULAN DAN SARAN}

Musik instrumental dengan menggunakan alat musik tradisional Mandar pada persalinan kala I fase aktif dimana hasil penelitian diuji berdasarkan uji Wilcoxon efektif menurunkan skala nyeri pada ibu bersalin saat his (kontraksi uterus) dengan adanya perubahan yang signifikan sebelum dan setelah diberikan intervensi.

Saran peneliti untuk tempat pelayanan persalinan, sebaiknya dapat menfasilitasi pemberian terapi non farmakologi seperti memperdengarkan musik instrumental.

\section{DAFTAR PUSTAKA}

Mander, Rosemary. (2003). Nyeri persalinan. Edisi bahasa indonesia. Alih bahasa: Bertha sugiono. Jakarta: EGC.

Maryunani, A., \& Sukaryati, Y. (2011). Senam Hamil, Senam Nifas dan Terapi Musik. Jakarta: Trans Info Media.

Muliati, E., Royati, O. F., \& Widyaningsih, Y. (2014). Buku Ajar Kesehatan Ibu dan Anak. Jakarta: Pusat Pendidikan dan Pelatihan Tenaga Kesehatan.

NK Soyomani, NW Armini, NLP Sri Erawati. (2017). Pengaruh Terapi Musik Klasik dan Musik Tradisional Bali Terhadap Intensitas Nyeri Persalinan Kala I Fase Aktif. Jurnal Bahana Kesehatan Masyarakat Vol 1 No 1. www.journal. poltekkesjambi.ac.id. diakses tanggal 20 Agustus 2020.

Rohani, et al. (2011). Asuhan Kebidanan Pada Masa Persalinan. Jakarta: Salemba Medika.

Yeyeh, R. A. (2012). Asuhan Kebidanan II Persalinan. Jakarta: Trans Info Medika.

Yongki, Judha, M., Rodiyah, \& Sudarti. (2012). Asuhan Pertumbuhan Kehamilan, Persalinan, Neonatus, Bayi dan Balita. Yogyakarta: Nuha Medika.

Husna, Ulya. (2010). Pengaruh Terapi Musik Instrumental Terhadap Perbedaan Intensitas Nyeri Persalinan Fase Aktif Kala I http://repo.unand.ac.id/388/. 